\title{
Effect of Cytosine Arabinoside and Two of Its Analogues on Herpes Simplex Virus Type 1 in Cell Cultures
}

\author{
Shigeniro Matsumoto, Toshio Suganuma and Nakao Ishida \\ Department of Bacteriology, Tohoku University School of Medicine, \\ Sendai
}

\begin{abstract}
Matsumoto, S., Suganuma, T. and Ishida, N. Effect of Cytosine Arabinoside and Two of Its Analogues on Herpes Simplex Virus Type I in Cell Cultures. Tohoku J. exp. Med., 1974, 114 (4), 393-394—The multiplication of herpes simplex virus type 1 was inhibited by cytosine arabinoside $\mathrm{HCl}$ (Ara C) and its cyclic derivative 2,2'-anhydro-1- $\beta$-D-arabinofuranosyl cytosine $\mathrm{HCl}$ (Cyclo $\mathrm{C}$ ). However, 2,2'-anhydro 1- $\beta$-D-arabinofuranosyl cytosine- $3^{\prime}$-phosphate (Cyclo CP) showed a negligible activity against HSV at relatively high concentration.

antiviral; $\mathrm{HSV}$; chemotherapy; ara $\mathrm{C}$; cyclo $\mathrm{C}$
\end{abstract}

Cytosine arabinoside (Ara $\mathrm{C}$ ) has antiviral activity against pox and herpes groups of DNA viruses (Buthala 1964). It is effective clinically against herpetic keratitis. Ara C is also active against RNA tumor virus, and shows antitumor activity against acute leukemia in mice. It has been used clinically to treat acute leukemia and lymphoma. $2,2^{\prime}$-Anhydro-1- $\beta$-D-arabinofuranosyl cytosine $\mathrm{HCl}$ (Cyclo $\mathrm{C}$ ) was recently found to be a potent inhibitor of L-1210 tumor and to differ from Ara C in its resistance to nucleoside deaminase (Hoshi et al. 1972). This report compares the effect of Ara $\mathrm{C}$ with that of Cyclo $\mathrm{C}$ and another analogue, $2,2^{\prime}$-anhydro-1- $\beta$-D-arabinofuranosyl cytosine-3'-phosphate (Cycle CP) on the multiplication of HSV in HeLa cells.

Ara $\mathrm{C}$ and Cyclo $\mathrm{C}$ were kindly supplied by Kojin Co., Ltd., Tokyo. Cyclo CP was synthesized by Dr. J. Nagyvary (1969), Department of Biochemistry and Biophysics, Texas A and M University, College Station, Texas (1969). HSV was propagated in HeLa cells. The titer of stock virus was $10^{7} \mathrm{TCID}_{50} / \mathrm{ml}$ in the same cells. HeLa cells were grown on glass in Earle's saline supplemented with $0.1 \%$ yeast extract, $0.5 \%$ lactalbumin hydrolysate (YLE) and $10 \%$ bovine serum. The cultures were maintained in YLE with $2 \%$ heated horse serum. Virus infection was carried out as follows. The tube cultures were infected with HSV at a multiplicity of input of 3. Unadsorbed virus was removed after $1 \mathrm{hr}$, the cultues were washed and then $1 \mathrm{ml}$ of maintenance medium containing test compounds was added to the cultures. Incubation was carried out at $37^{\circ} \mathrm{C}$. Eighteen $\mathrm{hr}$ later, cells suspended in medium were taken, frozen and thawed 3 times, and titrated for virus infectivity in HeLa cells.

The results are summerized in Table 1. Ara $\mathrm{C}$ and Cyclo $\mathrm{C}$ markedly inhibited the multiplication of HSV at a concentration of more than $0.5 \mu \mathrm{g} / \mathrm{ml}$, but Cyclo CP scarcely blocked the growth of HVS even at $5 \mu \mathrm{g} / \mathrm{ml}$, a concentration which caused slight cytotoxicity to the cells. Ara $\mathrm{C}$ and Cyclo $\mathrm{C}$ appeared similar in their antiviral activity against HSV in vitro and only different in sensitivity to cytosine deaminase (Hoshi et al. 1972). On the other hand, the antiviral activity of Cyclo CP was not so effective as these two

Received for publication, November 6, 1974 
TABLE 1. Inhibition on the multiplication of herpes simplex virus type 1 by Ara $C$ and two of its anxlogues

\begin{tabular}{cccc}
\hline $\begin{array}{c}\text { Concentration } \\
\mu \mathrm{g} / \mathrm{ml}\end{array}$ & \multicolumn{3}{c}{ HSV titer* $\left(\log _{10}\right)$} \\
\cline { 2 - 4 } & Ara $\mathrm{C}$ & Cyclo $\mathrm{C}$ & Cyclo CP \\
\hline 5.0 & 2.0 & 2.5 & 5.5 \\
1.0 & 3.5 & 3.5 & 5.5 \\
0.5 & 4.5 & 4.0 & 5.5 \\
0.1 & 5.5 & 5.0 & 6.0 \\
0.05 & 5.5 & 6.5 & 6.0 \\
0 & 6.5 & 6.5 & 6.5 \\
\hline
\end{tabular}

* $\mathrm{TCD}_{50} / \mathrm{ml}$.

compounds. This may indicate that the phospholization occurs in vitro resulting in the inhibition of the uptake of that compound by cell cultures, with the former two compounds.

In addition, none of the three compounds inhibited the replication of poliovirus type 1, rhinovirus 1A, influenza/PR8/34 $\left(\mathrm{H}_{0} \mathrm{~N}_{1}\right)$, parainfluenza/Sendai and vesicular stomatitis virus, but all inhibited vaccinia virus replication in vitro. No further information is available concerning the mode of action of Cyclo $\mathrm{C}$ and Cyclo CP on HSV replication.

\section{References}

1) Buthala, D.A. (1964) Cell culture studies on antiviral agents: I. Action of cytosine arabinoside and some comparisons with 5-iodo-2-deoxyuridine. Proc. Soc. exp. Biol. Med. (N.Y.), 115, 69-77.

2) Hoshi, A., Kanzawa, F. \& Kuretani, K. (1972) Antitumor activity of cyclocytidine in a variety of tumors. Gann, 63, 353-360.

3) Nagyvary, J. (1969) Arabinonucleotides. II. The synthesis of $0^{2},-2^{\prime}$-anhydrocytidine $3^{\prime}$-phosphate, a precursor of $1 \cdot \beta-\mathrm{D}$ - arabinosylcytosine. $J$. Amer. chem. Soc., 91, $5409-5410$. 